\title{
Revised taxonomy of selected fossil endocarp species in the Menispermaceae using a morphometric approach
}

\author{
Frédéric M. B. JACQUES \\ Key Laboratory of Biodiversity and Biogeography, \\ Kunming Institute of Botany, the Chinese Academy of Sciences, \\ no. 132 Lanhei Road, Heilongtan, Kunming, Yunnan 650204 (P. R. China) \\ and Nanjing Institute of Geology and Palaeontology, \\ the Chines Academy of Sciences, \\ no. 39 East Beijing Road, Nanjing, Jiangsu 210008 (P. R. China) \\ frederic.jacques@nigpas.ac.cn \\ Christopher Yu-Sheng LIU \\ Department of Biological Sciences and Don Sundquist Center of \\ Excellence in Paleontology, East Tennessee State University, Johnson City, \\ Tennessee 37614-1710 (USA) \\ liuc@etsu.edu (corresponding author) \\ Edoardo MARTINETTO \\ University of Torino, Dipartimento di Scienze della Terra, Via Valperga \\ Caluso 35, 10125 Torino (Italy) \\ edoardo.martinetto@unito.it \\ Zhe-Kun ZHOU \\ Key Laboratory of Biodiversity and Biogeography, \\ Kunming Institute of Botany, the Chinese Academy of Sciences, \\ no. 132 Lanhei Road, Heilongtan, Kunming, Yunnan 650204 (P. R. China) \\ zhouzk@mail.kib.ac.cn (corresponding author)
}

Jacques F. M. B., Liu C. Y.-S., Martinetto E. \& Zhou Z.-K. 2011. - Revised taxonomy of selected fossil endocarp species in the Menispermaceae using a morphometric approach. Geodiversitas 33 (1): 177-197. DOI: 10.5252/g2011n1a8.

\begin{abstract}
Several Cenozoic endocarp remains from the northern hemisphere have been described with strong affinities to either Menispermum L. or Sinomenium Diels, a monophyletic group of menispermous vines. It has been proposed that all of these fossil species are synonymous and should be included within Sinomenium. In order to evaluate this suggestion, we have studied the morphological variation ranges in the menispermous endocarps with geometric morphometrics, and then the ranges of the selected fossil endocarps is compared to the ranges of modern endocarps. The shape of each endocarp is described using eight landmarks and 17 semilandmarks, accounting for the outline and the positions of lateral
\end{abstract}


KEY WORDS

Menispermaceae,

Menispermum,

Sinomenium,

morphometrics, semilandmark, fossil. ridge and foramen on the endocarps. Endocarp ornamentation is studied by statistical comparisons of the number of transverse ridges. It is concluded that the ranges of variation within the fossil genera, all morphologically related to horseshoe-shaped endocarps in Menispermaceae, are found not to be greater than that in the only extant species of Sinomenium, S. acutum (Thunb.) Rehder \& Wilson. Sinomenium macrocarpum Liu \& Jacques, 2010 differs from the other fossil species of Sinomenium by its higher number of transverse ridges. All other fossil species of Sinomenium, except $S$. macrocarpum, and Wardensheppeya Eyde, 1970 are synonymous. Menispermum? taylori Chandler, 1964 is transferred to Sinomenium. The fossil genus Palaeosinomenium Chandler, 1961 is confirmed through the obliquity of its endocarp, but all species are found to be synonymous. Menispermicarpum rariforme Chandler, 1961 is also included in Palaeosinomenium.

\section{RÉSUMÉ}

Taxonomie révisée de certaines espèces d'endocarpes fossiles de Menispermaceae par une approche morphométrique.

Plusieurs restes d'endocarpes du Cénozoïque de l'hémisphère nord ont été décrits comme ayant de fortes affinités avec soit Menispermum L. soit Sinomenium Diels, un groupe monophylétique de lianes des Menispermaceae. La synonymie de toutes ces espèces et leur inclusion dans Sinomenium ont déjà été proposées. Pour évaluer cette proposition, nous avons étudié l'étendue des variations morphologiques des endocarpes de Menispermaceae par morphométrie géométrique, et ensuite l'étendue de cette variation pour les espèces fossiles sélectionnées est comparée à l'étendue de la variation pour les espèces actuelles. La forme de chaque endocarpe est décrite grâce à huit landmarks et 17 semilandmarks, représentant le contour et les positions de la crête latérale et du foramen pour chaque endocarpe. L'ornementation des endocarpes est étudiée par une comparaison statistique du nombre de côtes transversales. On peut conclure que l'étendue de la variation dans les genres fossiles, tous morphologiquement liés aux Menispermaceae à endocarpes hippocrépiformes, n'est pas plus importante que celle observée dans la seule espèce actuelle de Sinomenium, S. acutum (Thunb.) Rehder \& Wilson. Sinomenium macrocarpum Liu \& Jacques, 2010 diffère des autres espèces fossiles de Sinomenium par son plus grand nombre de côtes transversales. Toutes les espèces fossiles de Sinomenium, à l'exception de $S$. macrocarpum, et de Wardensheppeya Eyde, 1970 sont synonymes. Menispermum? taylori Chandler, 1964 est transféré dans Sinomenium. Le genre fossile Palaeosinomenium Chandler, 1961 est confirmé par l'obliquité de son endocarpe, mais toutes ses espèces sont synonymes. Menispermicarpum rariforme Chandler, 1961 est aussi inclus dans Palaeosinomenium.

\section{INTRODUCTION}

Numerous menispermaceous fossil endocarps have been found in the temperate regions of North
America and Europe (e.g., Chandler 1961; Takhtajan 1974; Manchester 1994; Jacques \& De Franceschi 2005). As the most temperate genera in Menispermaceae are Menispermum L. and Sinomenium Diels 
(Diels 1910), it is not surprising that fossil endocarps showing the unique horseshoe-shaped outline have affinities with the Menispermum-Sinomenium complex. Molecular analyses also recognize this complex as monophyletic (Wang et al. 2007; Hoot et al. 2009; Jacques et al. 2011). A recent morphometric study on modern Menispermaceae endocarps (Jacques \& Zhou 2010) demonstrated that the endocarps from the Menispermum-Sinomenium complex have a different shape from other horseshoeshaped endocarps of the Menispermaceae. Fossils are placed in either Menispermum, Sinomenium, or in the extinct genera Wardensheppeya (Chandler) Eyde, 1970 and Palaeosinomenium Chandler, 1961. More than 15 fossil species have been described as part of this complex (Jacques 2009b), far more than the three to five species recognized in the modern flora. Palaeosinomenium (six species) and Wardensheppeya (three species) occur only in the Palaeogene, whereas the fossil species of Sinomenium (three fossil species) have been reported principally in the Neogene and sometimes in the Oligocene (Jacques 2009b). Menispermum (two fossil fruit species) occur in European Palaeogene and Neogene. Having considered that the range of shape variation of these fossil endocarps might fall within the range of the monotypic Sinomenium, Mai (1997) proposed a putative synonymy of Wardensheppeya and Palaeosinomenium with Sinomenium. However, the question has not yet been resolved. Furthermore, due to its key phylogenetic position in the basal eudicots (Savolainen et al. 2000; APGII 2003) and relatively rich fossil record (Doria et al. 2008; Jacques 2009b), Menispermaceae are critical and useful to provide evidence on the diversity of early eudicots.

Endocarps have a suite of systematically important characters. Both Diels (1910) and Kessler (1993) used seed and endocarp characters to discriminate between their tribes and genera. Furthermore, it is practical that the morphology of the menispermaceous endocarps is helpful in quick specimen identification (Jacques 2009a). Morphometry has been proven a powerful tool to characterize some of the modern endocarps (Jacques \& Zhou 2010).

The fossil species of the Menispermum-Sinomenium complex are mainly morphospecies based on endo- carp remains (Jacques 2009b). Attribution of the fossils to this complex is based on several diagnostic features (Jacques 2009a): horseshoe-shaped endocarps with excavated faces, bearing one lateral ridge on each face, and having a large central area largely ventrally opened, with a foramen near the stylar limb. Several fossil genera have been described in this complex based on several diagnostic features. Chandler (1961: 159) described Palaeosinomenium as having "a more oblique endocarp and elongate foramen" relative to Menispermum and Sinomenium. Palaeosinomenium species vary in the position of the foramen and the shape of the ventral margin (Chandler 1963). Wardensheppeya (under the name Wardenia) was characterized as having endocarps "with wide marginal flange" and "straight or concave ventral margin" by (Chandler 1961:158) and species vary in the position of the foramen and endocarp ornamentation (Chandler 1962, 1963). In contrast, for Sinomenium, the systematic treatment is quite different. Some species ( $S$. dielsii Szafer, 1947, S. militzeri Kirchheimer, 1943) were already transferred to $S$. cantalense (E.M.Reid) Dorofeev, 1955, synonymy accepted there on (e.g., Mai 1997). The fossil record of the latter species has long been reported from different localities and different ages (Table 1). The concept of $S$. cantalense is therefore broader than the concepts of Palaeosinomenium and Wardensheppeya species. The intraspecific variability of extant species is key to choose between a broad or narrow concept for the fossil species, but has not been analysed yet. Therefore, there is no clear evidence to support synonymizing some fossil species or in the continued recognition of others.

As diagnostic features used to distinguish among taxa refer to the endocarp shape, morphometric methods provide a mathematically based, less biased method to study and characterize shapes among taxa (Jensen 2003). Traditional morphometric methods have proved to be useful in the revision of Ampelocissus fossil seeds (Chen \& Manchester 2007).

When dealing with morphometrics, different methods are available (Jensen 2003; Adams et al. 2004). Traditional morphometrics deals with multivariate analysis of different measurements (Sokal \& Sneath 1963; Sneath \& Sokal 1973). Geometric morphometrics, first developed by Bookstein et al. 
TABLE 1. - Endocarps studied in the morphometrics analysis. *, Inclusion in this genus is not certain according to the authority.

\begin{tabular}{|c|c|c|c|}
\hline Species & $\begin{array}{c}\text { Number } \\
\text { of endocarps }\end{array}$ & Site & Age \\
\hline \multicolumn{4}{|l|}{ Menispermicarpum Chesters, 1957} \\
\hline M. rariforme Chandler, 1961 & 1 & London Clay & Eocene \\
\hline \multicolumn{4}{|l|}{ Menispermum Linnaeus, 1735} \\
\hline M. canadense Linnaeus, 1753 & 21 & $?$ & Recent \\
\hline "M. crassicarpum" cf. Reid \& Reid, 1915 & 1 & Tegelen & Late Pliocene \\
\hline M. dauricum DC., 1818 & 25 & $?$ & Recent \\
\hline M. reidii Geissert, Gregor \& Mai, 1990 & 1 & Sessenheim & $\begin{array}{l}\text { Late Miocene-Early } \\
\text { Pliocene }\end{array}$ \\
\hline M. cf. reidii Geissert, Gregor \& Mai, 1990 & 1 & Castelletto Cervo II, Italy & ?Late Pliocene \\
\hline M. taylori Chandler, $1964^{*}$ & 1 & London Clay & Eocene \\
\hline M. sp. & 1 & John day, Oregon & Oligocene \\
\hline \multicolumn{4}{|l|}{ Palaeosinomenium Chandler, 1961} \\
\hline P. hantonense Chandler, 1963 & 1 & London Clay & Eocene \\
\hline P. obliquatum (Chandler) Chandler, 1961 & 1 & London Clay & Eocene \\
\hline P. pulchrum Chandler, 1961 & 2 & London Clay & Eocene \\
\hline P. ucrainicum Dorofeev, 1974 & 4 & Ukraine & Eocene \\
\hline \multirow[t]{2}{*}{ P. venablesi Chandler, 1961} & 4 & London Clay & Eocene \\
\hline & 2 & Clarno Beds, Oregon & Eocene \\
\hline \multicolumn{4}{|l|}{ Sinomenium Diels, 1910} \\
\hline S. acutum (Thunb.) Rehder \& Wilson & 46 & & Recent \\
\hline \multirow{7}{*}{$\begin{array}{l}\text { S. cantalense (E.M.Reid, 1920) Dorofeev, } \\
1955\end{array}$} & 2 & Pont-de-Gail, France & Late Miocene \\
\hline & 1 & Ukraine & \\
\hline & 1 & Abkhazia & Miocene \\
\hline & 3 & Poland & Pliocene \\
\hline & 1 & Poland & Miocene \\
\hline & 26 & NW Italy & Pliocene \\
\hline & 20 & Cava Toppetti II, central Italy & Late Pliocene \\
\hline S. macrocarpum Liu \& Jacques, 2010 & 24 & Gray, Tennessee & $\begin{array}{l}\text { Late Miocene-Early } \\
\text { Pliocene }\end{array}$ \\
\hline S. sibiricum Dorofeev, 1974 & 4 & & Oligocene \\
\hline \multicolumn{4}{|l|}{ Wardensheppeya Eyde, 1970} \\
\hline \multirow[t]{2}{*}{ W. davisii (Chandler) Eyde, 1970} & 4 & London Clay & Eocene \\
\hline & 2 & Le Quesnoy, France & Eocene \\
\hline W. marginata (Chandler) Eyde, 1970 & 1 & London Clay & Eocene \\
\hline W. poolensis (Chandler) Eyde, 1970 & 2 & London Clay & Eocene \\
\hline
\end{tabular}

(1985), extracts size variation from the analysis and only deals with shape (Bookstein 1991). Geometric morphometric methods are very useful for the comparison of fossil and extant species, as some post-depositional processes could have modified the size of the fossil remains. In the landmark methods and Thin Plate Splines (TPS) analysis (Rohlf \& Slice 1990), an object is described by homologous landmarks (Bookstein 1991; Jensen 2003). These landmarks positions vary depending on the size, shape and orientation of each specimen (Adams et al. 2004). The analysis of landmarks begins with a superimposition process in order to remove size and orientation from the analysis (Bookstein 1986; Rohlf \& Slice 1990). The combination of landmark coordinates is then used as a descriptor of each object shape (Bookstein 1991; Adams et al. 2004). Landmark methods have been successfully used in some botanical studies (e.g., Jensen 1990; Shipunov \& Bateman 2005). However, the availability of only few homologous points on the studied endocarps limits the application of this landmark approach in the present study (Adams et al. 2004). The other type of morphometrics study is the study 
of outlines, using eigenshape analysis (Lohmann 1983) or elliptic Fourier functions (McLellan \& Endler 1998; Olsson et al. 2000). Outline methods are not congruent with different methods giving different results (Rohlf 1986; Adams et al. 2004). For the Menispermum-Sinomenium complex, the variation in ornamentation ranges from almost lacking to highly developed transverse ridges. Those ridges modify the outline and may interfere with the description of the general shape of an endocarp using outline methods. The solution to this problem is the semilandmark approach (Bookstein 1997), which enables the description of an object's outline using landmarks (Bookstein 1997; Monteiro et al. 2005) bearing only one Cartesian coordinate, namely the normal direction to the outline (Bookstein 2002). During the Procrustes superimposition procedure, the semilandmarks are allowed to slide along the outline. As the semilandmarks are placed on a curve, the difference in curvature between two specimens could increase the bending energy abnormally if they were fixed; therefore, we used sliding semilandmarks (i.e. they are allowed to slide along the outline). The combination of landmarks and semilandmarks can be successfully used in shape analysis (Monteiro et al. 2005). This approach, then, is the best to use for the case of fossil menispermous endocarps, viz. few homologous points but several homologous lines, as it has already been done for modern endocarps of the family (Jacques \& Zhou 2010). Geometric morphometrics has already been applied successfully in fossil studies, like on trilobites (Webster \& Hughes 1999; Delabroye \& Cronier 2008), ostracods (Aiello et al. 2007), sharks (e.g., Nyberg et al. 2006; Whitenack \& Gottfried 2010), reptiles (e.g., Bonnan 2007; Bonnan et al. 2008), and humans (e.g., Harvati 2003; Holliday et al. 2010). But, to our knowledge, it is the first to be applied in palaeocarpology.

The present study aims first to estimate intraspecific shape variability in the modern species of Menispermum and Sinomenium and allied fossil species; secondly to describe shape differences between these species and genera; and finally to propose a revision of the considered fossil endocarps and a revised systematic of the group.

\section{MATERIAL AND METHODS}

\section{SAMPLING AND DIGITIZATION}

This study included 92 extant and 111 fossil endocarps, representing 18 species of Sinomenium-Menispermum complex (Table 1; Appendix 1). Modern endocarps were taken from herbarium sheets and photographed under a stereoscopic microscope (Nikon SMZ1500) coupled with a digital camera (Nikon digital sight DS-U). Pictures of fossil endocarps were scanned from publications or taken by the authors. Italian specimens pictured for the study are mainly from the following Pliocene localities: Ca' Viettone (Martinetto 1995), Castelletto Cervo I (Cavallo \& Martinetto 2001), Cava Toppetti II (Martinetto 2001), Sento (Basilici et al. 1997), Ronco Biellese (Martinetto 1995), Villafranca d'Asti (Martinetto 1995). As neither pictures nor complete specimens are available, Palaeosinomenium becvae Knobloch, 1971 was not included in this study. Because Althaea crassicarpa Reid \& Reid, 1915 was already compared with Menispermum by Reid (1920) and Geissert et al. (1990), we included it under the name "Menispermum crassicarpum". We included Menispermicarpum rariforme Chandler, 1961 in our study, despite of its unsolved affinities, but it could be allied with the Menispermum-Sinomenium group. Actual holotypes of all fossil species except S. sibiricum Dorofeev, 1974 have been observed by the authors.

\section{DATA ACQUISITION}

The same lateral face of each specimen was digitized using TPSdig (Rohlf 2006a). All these images were captured at a resolution of $640 \times 480$ pixels. When the specimens from the literature were not figured showing this same face, we horizontally flipped the picture (both faces are approximately symmetric) to provide a consistent face orientation for shape analysis. The outline was determined by hand using "curve drawing tools". The same technique was used to digitize the top of the lateral ridge. All lines start and finish on landmark points. The lines are re-sampled to equally distant points: nine for the dorsal margin (numbers 3 to 11), six for the ventral margin (numbers 20 to 25) and eight for the lateral ridge (numbers 12 to 19). Landmarks describing those lines, except their extremities, were 


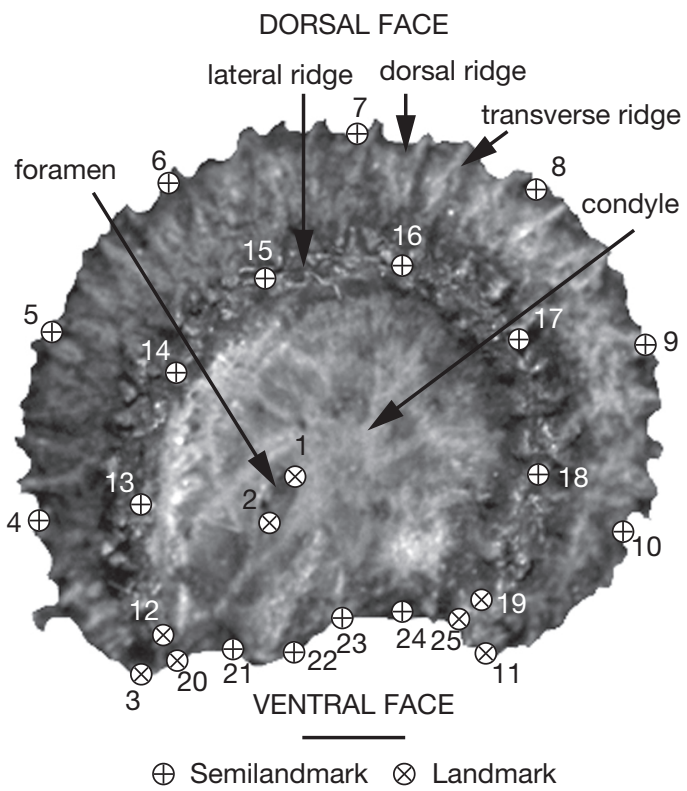

FIG. 1 - Position of landmarks and semilandmarks on a Menispermaceae endocarp. Scale bar: $1 \mathrm{~mm}$.

TABLE 2. - Description of landmarks. For definition of landmark types see Slice et al. (1996). Landmark numbers refer to Figure 1.

\begin{tabular}{clc}
\hline $\begin{array}{l}\text { Landmark } \\
\text { number }\end{array}$ & Description & $\begin{array}{c}\text { Landmark } \\
\text { type }\end{array}$ \\
\hline 1 & $\begin{array}{l}\text { Dorsal endpoint of the } \\
\text { foramen } \\
\text { Ventral endpoint of the }\end{array}$ & II \\
2 & foramen & II \\
3 & End of stylar limb & I \\
11 & Styd of the other limb & I \\
12 & Other end of lateral ridge & II \\
20 & Point on ventral margin & III \\
& $\begin{array}{l}\text { corresponding to the base of } \\
\text { lateral ridge, stylar side } \\
25\end{array}$ & $\begin{array}{l}\text { Point on ventral margin } \\
\text { corresponding to the base of } \\
\text { lateral ridge, other side }\end{array}$ \\
&
\end{tabular}

changed to semilandmarks using TPSutil (Rohlf 2006b). The endocarp shape was then described using eight landmarks and 17 semilandmarks (Fig. 1; Table 2).

In addition, the number of transverse ridges was counted for each specimen.

\section{DATA ANALYSIS}

The shapes for each specimen were then aligned using General Procrustes Analysis with semilandmarks allowed to slide. The consensus shape was combined, and partial warps and relative warps (using $\alpha=0$ ) were calculated, using the software TPSrlw (Rohlf 2007). The relative warps analysis corresponds to the Principal Component Analysis (PCA) of all partial warps scores (Rohlf 1993; Rohlf et al. 1996). The PCA is preferred to Canonical Variance Analysis (CVA) because PCA does not require a priori grouping of the specimens whereas CVA does. CVA maximizes the difference between groups compared to differences within groups (Rohlf et al. 1996). As this study addresses the limits of the species, we prefer not to work with a priori groupings.

All partial warp scores were also used for a multivariate analysis. The similarity between seven groups (Menispermum canadense L., Menispermum dauricum DC., Sinomenium acutum (Thunb.) Rehder \& Wilson, Sinomenium macrocarpum Liu \& Jacques, other fossil Sinomenium, Palaeosinomenium, and Wardensheppeya) was tested using a non-parametric test, a one-way ANOSIM with Euclidean distance and 100000 permutations (Clarke 1993). This choice was made because of the small sample size of some groups.

The number of transverse ridges was tested for equality between those seven groups. The hypothesis of normality was rejected for Menispermum dauricum (Shapiro-Wilk test: W=0.503, $\mathrm{p}=0.001782$ ), so an ANOVA could not be used. Therefore, we used a non-parametric test, the Kruskal-Wallis test. In case of different means, post-hoc tests were performed based on Bonferroni-corrected pairwise Mann-Whitney test.

Due to the limitation of specimens, the following two fossil species, Menispermum? taylori Chandler, 1964 and Menispermicarpum rariforme, were not included in the statistic analyses. Some other species with only one specimen were grouped with other congeneric species for the statistical analysis, for example, Palaeosinomenium obliquatum (Chandler) Chandler, 1961 was grouped with all Palaeosinomenium.

All statistical analyses were performed with the software PAST version 1.75b (Hammer et al. 2001). 


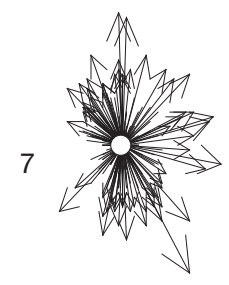

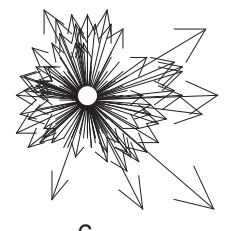

6
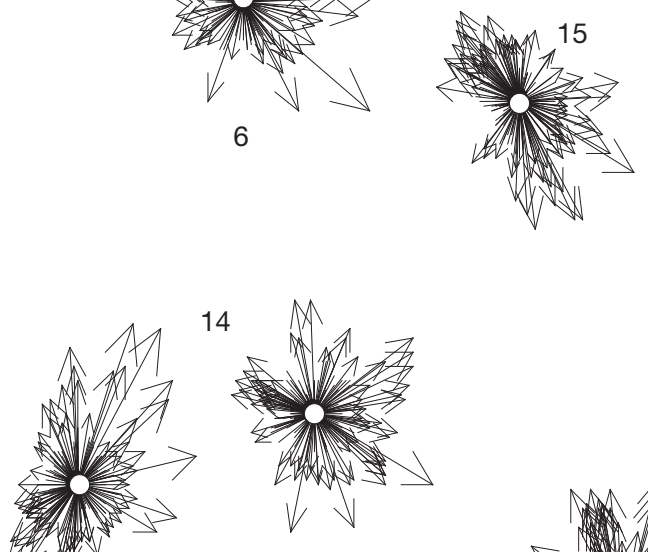

5

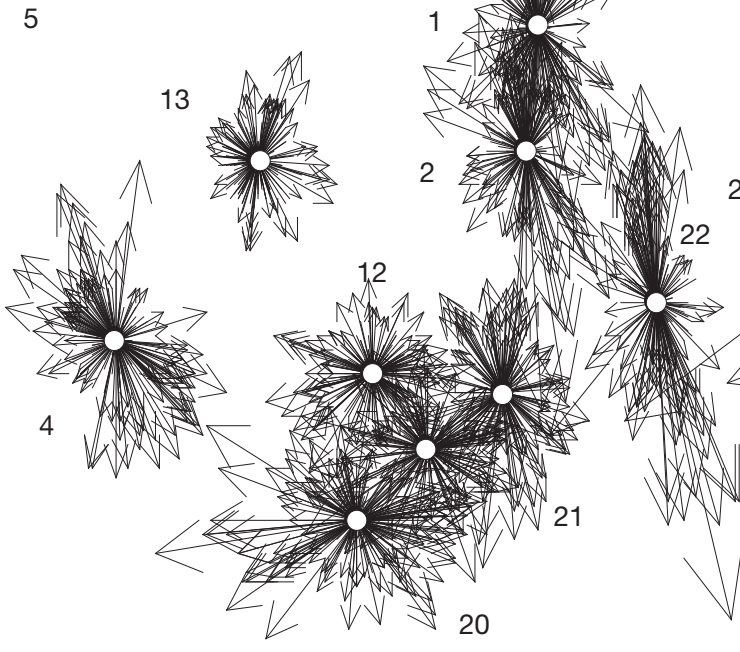

3
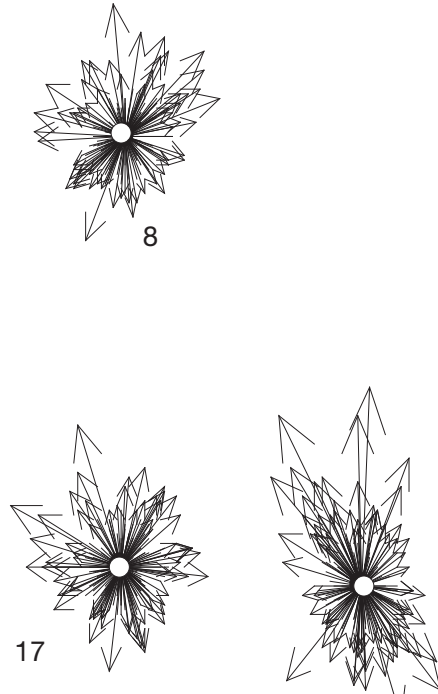

9
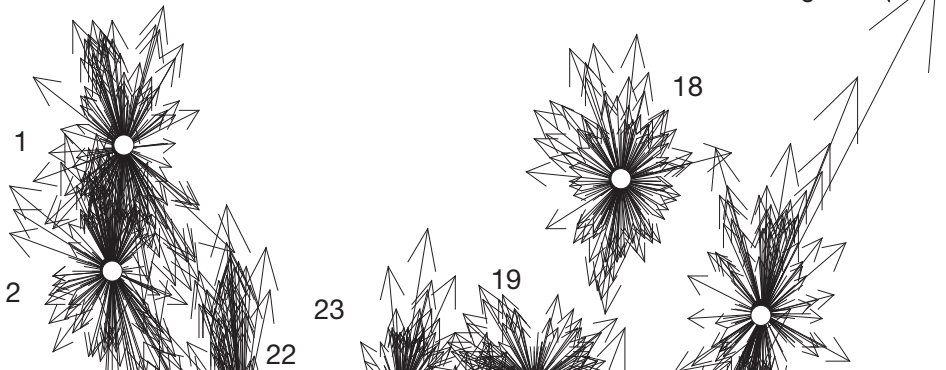
mens must have the same number of landmarks (Adams et al. 2004).

The method studies the global shape of the object. If the shape of the object has been modified, the method analyses the deformed shape and not the original one of the object. If the deformation is exactly known, the actual shape can be reconstructed and analysed. Fossil endocarps might have undergone some deformation. However, we cannot reconstruct such deformation; therefore, we exclude from this analysis all clearly deformed endocarps.

Another problem might be differences in fossil preservation that can affect ornamentation. For ornamentation, we only use the number of transversal ridges and neither their size nor their shape (more or less thin or spiny) is considered; therefore we assume that, as long as transverse ridges are present, preservation process did not change their number. For the shape of endocarp, the method used in the present study, geometric morphometrics, excludes size from the analysis (Bookstein 1991), and therefore accounts for homothetic size differences due to preservation process. In case of non homothetic differences, this is a deformation and clearly deformed endocarps are excluded.

\section{ABBREVIATIONS}

ANOSIM Analysis of similarity;

ANOVA Analysis of variance.

\section{RESULTS}

\section{CONSENSUS AND MEAN SHAPES}

Figure 2 shows the consensus positions of landmarks and semilandmarks, as well as the vectors to all positions in the sampling, resulting from the General Procrustes Analysis. The most evident variation is observed in the ventral margin region.

A consensus for each group was calculated (Fig. 3). The grid, representing the thin-plate transformation from the general consensus to the group consensus, allows characterization of the peculiar shape of each group possible relative to the overall consensus shape. Menispermum canadense (Fig. 3A) shows a strong concavity of the ventral margin and a relatively larger condyle than the consensus shape. Menispermum dauricum (Fig. 3B) also shows a strong concavity of the ventral margin, but with a condyle only slightly relatively larger than that of $M$. canadense. Sinomenium acutum (Fig. 3C) is very similar in shape with the consensus shape. Sinomenium macrocarpum (Fig. 3D) has a consensus very similar to that of $S$. acutum. Other fossil Sinomenium (Fig. 3E) have a relatively higher dorso-ventral length and a relatively shorter limbto-limb length than the consensus shape, and the extremities of the two limbs are relatively closer than the consensus shape. Wardensheppeya (Fig. 3F) has a relatively smaller condyle and relatively closer extremities of the two limbs than the consensus shape. Palaeosinomenium (Fig. 3G) has an almost flat ventral margin, a relatively small condyle and an obliquity of the whole endocarp.

\section{RELATIVE WARPS ANALYSIS}

The results of relative warps analysis are summarised by the representation of the first two main axes (Fig. 4; Table 3). The first relative warp axis discriminates most of the groups and corresponds to a modification of the concavity of the ventral margin, a contraction of the median length and a relative increase of dorsal flange size (or relative decrease of condyle size). The second relative warp axis discriminates between the recent and fossil Sinomenium and corresponds to an increase of the length relative to the height, a removal of the two limb extremities and a relative increase of dorsal flange size. Other relative warp axes do not discriminate between groups. There is some overlap between the groups. The shape of Menispermum dauricum is between those of Sinomenium acutum and $M$. canadense. Wardensheppeya is set between other fossil Sinomenium and Palaeosinomenium. Sinomenium acutum endocarps show a wide variability in shape.

The ANOSIM gives the following result, viz. mean rank within 6490, mean rank between 10710 , $\mathrm{R} 0.4246, \mathrm{p}($ same $)<1 \times 10^{-5}$. The hypothesis of similarity among the seven groups is rejected. Table 4 summarises the results of the post-hoc pairwise comparisons tests. The test is significant at $1 \%$ for all pairwise comparisons (hypothesis of similar- 
A

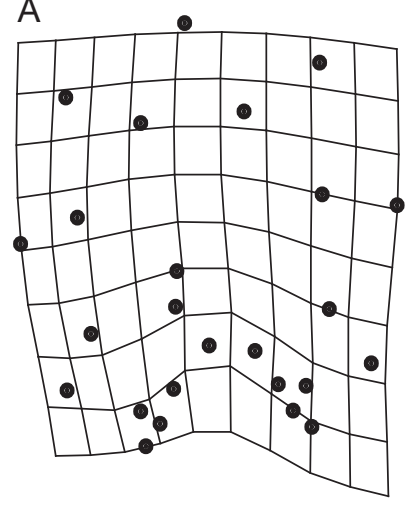

D

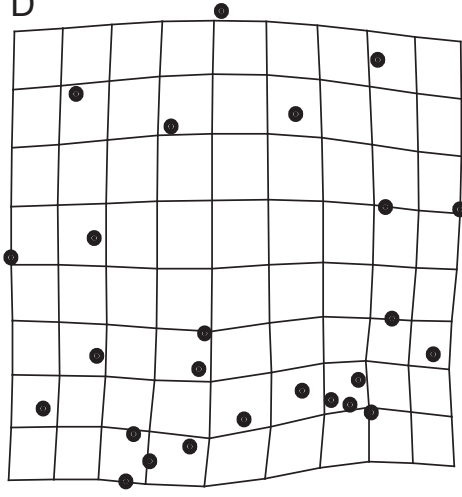

G

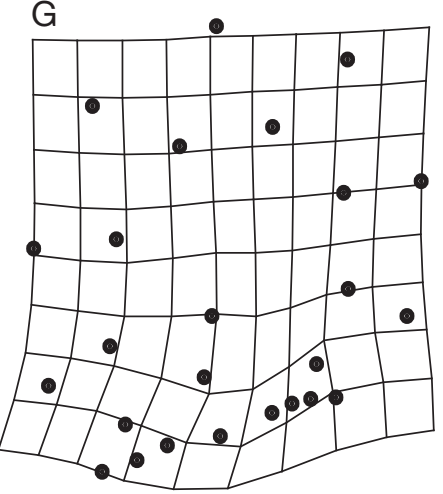

B

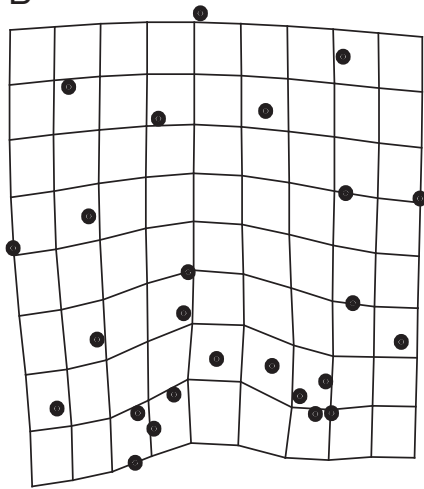

E

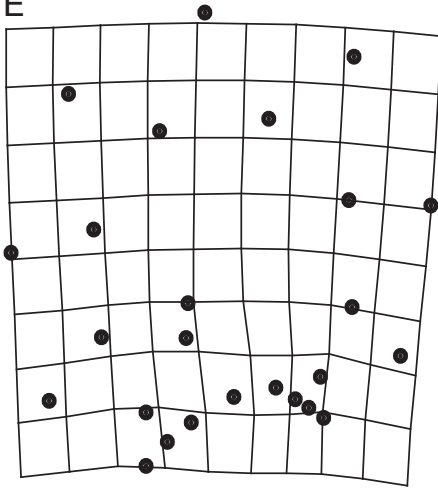

C

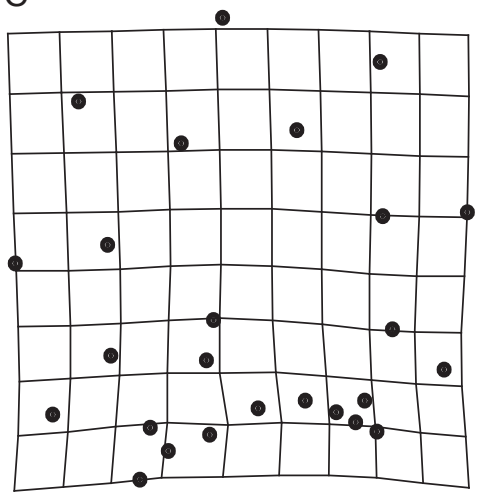

$\mathrm{F}$

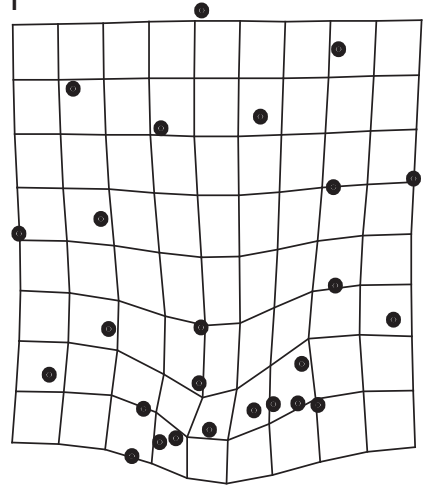

FIG. 3 - Consensus shape for each group of endocarp. The grid corresponds to the thin-plate transformation between the general consensus and the consensus of each group: A, Menispermum canadense L.; B, Menispermum dauricum DC.; C, Sinomenium acutum (Thunb.) Rehder \& Wilson; D, Sinomenium macrocarpum Liu \& Jacques, 2010; E, other fossil Sinomenium Diels; F, Wardensheppeya Eyde, 1970; G, Palaeosinomenium Chandler, 1961.

ity rejected) except for other fossil Sinomenium and M. dauricum; S. acutum and S. macrocarpum; Palaeosinomenium and Wardensheppeya. For Pala- eosinomenium and Wardensheppeya, and M. dauricum and other fossil Sinomenium, the test is significant at $5 \%$. 
TABLE 3. - Singular values and percent explained by relative warps axes.

\begin{tabular}{cccc}
\hline $\begin{array}{l}\text { Relative } \\
\text { warps axis }\end{array}$ & $\begin{array}{l}\text { Singular } \\
\text { value }\end{array}$ & $\begin{array}{l}\text { Percent } \\
\text { explained }\end{array}$ & $\begin{array}{l}\text { Cumulative } \\
\text { percent explained }\end{array}$ \\
\hline 1 & 1.0316 & 35.52 & 35.52 \\
2 & 0.7401 & 18.17 & 53.69 \\
3 & 0.5899 & 11.56 & 65.25 \\
4 & 0.4634 & 7.16 & 72.41 \\
5 & 0.4045 & 5.46 & 77.87 \\
\hline
\end{tabular}

\section{ANALYSIS OF ORNAMENTATION}

The number of transverse ridges for each group varies greatly, ranging from 11 to 44 (Fig. 5). Menispermum canadense has the highest number of transverse ridges, whereas Sinomenium (including both recent and fossil), Palaeosinomenium and Wardensheppeya have the lowest number of ridges. The number of ridges in $M$. dauricum is intermediate between those of $M$. canadense and $S$. acutum. The number of ridges in $S$. macrocarpum is intermediate between that of $M$. dauricum and other Sinomenium and Wardensheppeya.

The Kruskal-Wallis test gives $\mathrm{p}=2.267 \times 10^{-22}$, rejects the hypothesis of equality of means, and is followed by Mann-Whitney pairwise comparison post-hoc tests (Table 5). The p-values are significant for $M$. canadense and all other groups, and for $M$. dauricum and all other groups, except $S$. macrocarpum. The hypothesis of equality of ridge number cannot be rejected between $S$. acutum, fossil Sinomenium (except S. macrocarpum) Palaeosinomenium and Wardensheppeya. The test is significant at $5 \%$ between S. macrocarpum and Wardensheppeya.

\section{DISCUSSION}

\section{THE SHAPE SIGNAL}

The maximal shape variation is observed on the ventral margin (Fig. 2). The dorsal margin is represented by many semi-landmarks, whereas the ventral margin groups more landmarks (Fig. 1). Therefore, the concentration of the variation near the ventral margin could be an artefact. However, the variation observed at the ventral margin concerns changes in the concavity of the ventral margin
(Fig. 3), and then represents a real shape signal. On the contrary, there is no change in the convexity of the dorsal margin.

Transverse ridges may be a source of other homologous points, and hereby of other landmarks. However, the number of transverse ridges is not constant even in the same species (Fig. 5). Besides, all transverse ridges of one endocarp are of similar structure, as we cannot discriminate between them. Therefore, we cannot reconstruct homologies (if they do exist).

\section{INFRAGENERIC RELATIONSHIPS}

The relative warp analysis (Fig. 4) exhibits the shape differences between specimens. A detail of the results is given for the fossil specimens (Fig. 6). The positions of the different species of the same genus occupy the same morphospace. For example, the postion of several endocarps of Wardensheppeya davisii (Chandler) Eyde, 1970 in the graph appears to surround that of the only known specimen of W. marginata (Chandler) Eyde, 1970. Palaeosinomenium obliquatum is plotted at almost the same position as one (of six) specimen of $P$. venablesi Chandler, 1961. Each fossil genus, in morphospace, represents less variability than in extant $S$. acutum, as they occupy a smaller area of the plot. When describing the different species of Wardensheppeya (under the name Wardenia), Chandler (1961, 1962, 1963) discriminated between the species based on their shape and, and to a lesser degree, their ornamentation. Having used morphometrics, we noticed that the shape does not represent a diagnostic character useful for discriminating in species of Wardensheppaya and Palaeosinomenium. There are also variations in endocarp ornamentation within the modern species, e.g., $M$. dauricum varies from almost smooth to having pronounced transverse ridges. Similarly, although the species in Palaeosinomenium from the Eocene London Clay were defined primarily by their shapes (Chandler 1925, 1961, 1963), the present morphometric study clearly shows that this feature cannot be safely applied in fossil endocarp determination. Chandler (1961) stated that P. pulchrum Chandler, 1961 displays a greater obliquity than P. venablesi; however, our results (Fig. 6) show that the obliquity of $P$. pulchrum is not greater than 


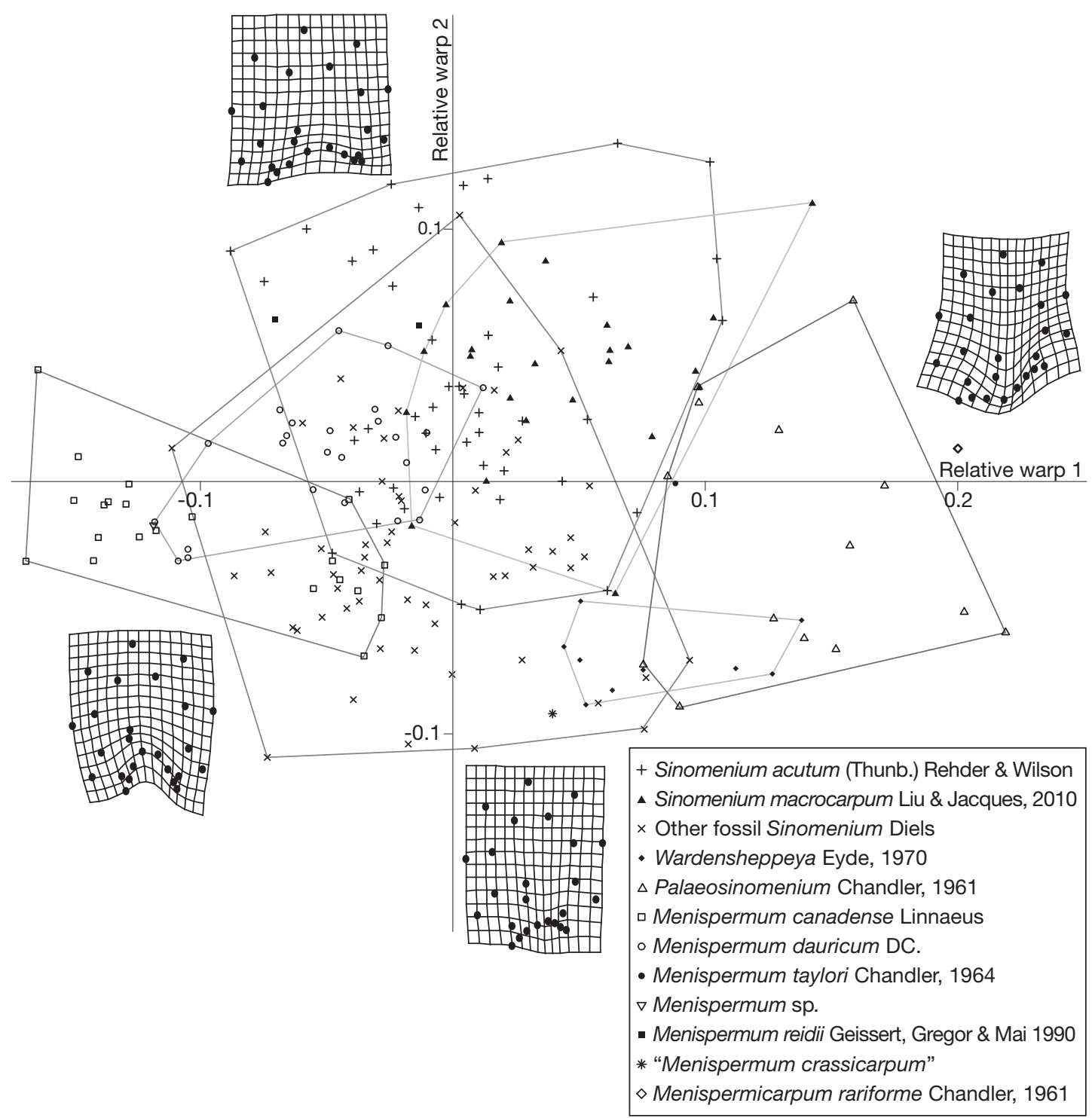

FIG. 4 - Relative warps analysis of shape of Menispermaceae endocarps, axes 1 and 2. The sketches along the axes correspond to the shape modification. Hulls surround each group.

that of $P$. venablesi. Furthermore, our morphometric analysis supports that all the fossil specimens of Sinomenium examined in the present study, except S. macrocarpum, can be grouped into one species. Despite the morphological similarity with $S$. acutum (Fig. 4; Table 4), S. macrocarpum differs from the former in its ornamentation (Fig. 5; Table 5).
As the difference between them is based only on ornamentation, their inclusion in the same genus seems correct. The fossil record of $S$. cantalense shows that this fossil species appears extremely diverse and exhibits a wide range of variations. To better examine the diversity of this fossil species, we separated the specimens according to their localities 
TABLE 4. - ANOSIM post-hoc pairwise comparison of shape of Menispermaceae endocarps. Lower-half values are Bonferroni corrected $\mathrm{p}$-values. Upper-half values are uncorrected p-values. Abbreviations: ${ }^{*}$, significant test at $1 \%$; ${ }^{*}$, significant test at $5 \%$; 0 , indicates a result lower than the lowest value that can be displayed by the software; M., Menispermum; S., Sinomenium.

\begin{tabular}{|c|c|c|c|c|c|c|c|}
\hline \multirow[b]{2}{*}{ M. canadense } & \multirow[t]{2}{*}{$\begin{array}{l}\text { M. cana- } \\
\text { dense }\end{array}$} & \multicolumn{2}{|c|}{ M. dauricum S. acutum } & \multirow{2}{*}{$\begin{array}{l}\text { S. macro- } \\
\text { carpum } \\
0\end{array}$} & $\begin{array}{l}\text { Other fossil } \\
\text { Sinomenium }\end{array}$ & $\begin{array}{l}\text { Palaeo- } \\
\text { sinomenium }\end{array}$ & \multirow{2}{*}{$\begin{array}{l}\text { Warden- } \\
\text { sheppeya }\end{array}$} \\
\hline & & $2.0 \times 10^{-5}$ & 0 & & 0 & 0 & \\
\hline M. dauricum & $5.6 \times 10^{-4^{\star *}}$ & & 0 & 0 & $4.5 \times 10^{-4}$ & 0 & 0 \\
\hline S. acutum & $0^{\star *}$ & 0 ** & & 0.01874 & 0 & 0 & 0 \\
\hline S. macrocarpum & $0^{\text {** }}$ & $0^{\star *}$ & 0.5247 & & 0 & 0 & 0 \\
\hline Other fossil & $0^{* *}$ & $0.0126^{\star}$ & $0^{\star \star}$ & $0^{\star \star}$ & & 0 & $1.0 \times 10^{-5}$ \\
\hline \multicolumn{8}{|l|}{ Sinomenium } \\
\hline Palaeosinomenium & 0 ** & 0 ** & $0^{\star *}$ & $0^{\star *}$ & $0^{\star \star}$ & & $3.8 \times 10^{-4}$ \\
\hline Wardensheppeya & $0^{\text {** }}$ & $0^{\text {** }}$ & $0^{\star *}$ & $0^{\text {** }}$ & $2.8 \times 10^{-4 * *}$ & $0.0106^{\star}$ & \\
\hline
\end{tabular}

TABLE 5. - Mann-Whitney pairwise comparison post-hoc test for equality of means (number of transverse ridges on endocarps). Upper-half values, uncorrected $p$ values. Lower-half values, Bonferroni corrected $p$-values. Abbreviations: ${ }^{* *}$, significant test at $1 \%$; *, significant test at $5 \% ; \mathbf{1}$, indicates that the resolution of the software cannot distinguish the actual value from $1 ; \boldsymbol{M}$., Menispermum; S., Sinomenium.

\begin{tabular}{|c|c|c|c|c|c|c|c|}
\hline & $\begin{array}{l}\text { M. cana- } \\
\text { dense }\end{array}$ & $\begin{array}{l}\text { M. dauri- } \\
\text { cum }\end{array}$ & S. acutum & $\begin{array}{l}\text { S. macro- } \\
\text { carpum }\end{array}$ & $\begin{array}{l}\text { Other fossil } \\
\text { Sinomenium }\end{array}$ & $\begin{array}{l}\text { Palaeo- } \\
\text { sinomenium }\end{array}$ & $\begin{array}{l}\text { Warden- } \\
\text { sheppeya }\end{array}$ \\
\hline M. canadense & & 0.0003845 & $6.963 \times 10^{-11}$ & $2.658 \times 10^{-8}$ & $2.22 \times 10^{-11}$ & $1.438 \times 10^{-6}$ & $2.099 \times 10^{-5}$ \\
\hline M. dauricum & $0.008075^{\star \star}$ & & $4.489 \times 10^{-10}$ & 0.01552 & $8.188 \times 10^{-12}$ & $4.895 \times 10^{-6}$ & $6.302 \times 10^{-5}$ \\
\hline S. acutum & $1.462 \times 10^{-9 * \star}$ & $9.428 \times 10^{-9 * *}$ & & $3.592 \times 10^{-6}$ & 0.1928 & 0.2646 & 0.4737 \\
\hline $\begin{array}{l}\text { S. macro- } \\
\text { carpum }\end{array}$ & $5.583 \times 10^{-7^{\star *}}$ & 0.3259 & $7.543 \times 10^{-5^{\star \star}}$ & & $5.115 \times 10^{-8}$ & 0.001406 & 0.0001854 \\
\hline $\begin{array}{l}\text { Other fossil } \\
\text { Sinomenium }\end{array}$ & $4.662 \times 10^{-10^{\star *}}$ & $1.719 \times 10^{-10^{\star *}}$ & 1 & $1.074 \times 10^{-6^{* *}}$ & & 0.6232 & 0.9461 \\
\hline $\begin{array}{l}\text { Palaeo- } \\
\text { sinomenium }\end{array}$ & $3.02 \times 10^{-5 * *}$ & $0.0001028^{\star \star}$ & 1 & $0.02953^{*}$ & 1 & & 0.9202 \\
\hline $\begin{array}{l}\text { Warden- } \\
\text { sheppeya }\end{array}$ & $0.0004408^{* *}$ & $0.001324^{* *}$ & 1 & $0.003893^{\star *}$ & 1 & 1 & \\
\hline
\end{tabular}

or taxonomic synonym, i.e. France (Pont-de-Gail), northwestern italy, central Italy, eastern Europe, and "S. militzeri", a fossil species already included in $S$. cantalense. It should be noted that a slight shape difference among specimens from northwestern and central Italy exist, i.e. specimens from central Italy are the most recent (Late Pliocene) and are the most similar to modern ones, whereas specimens from north-western Italy are slightly older in age (Pliocene) and are more similar to Wardensheppeya. This suggests that the evolution from the oldest form (represented by Wardensheppeya) to the modern ones might have been gradual.

\section{GENERIC RELATIONSHIPS}

It is clear that the first relative warp axis permits separations of most genera (Fig. 4), namely Menispermum,
Sinomenium and Palaeosinomenium. However, this axis does not allow us to distinguish between Wardensheppeya and Sinomenium. On a morphometric basis, we follow the proposition of Mai (1997) for a synonymy between Wardensheppeya and Sinomenium. However, we reject the proposed synonymy of Palaeosinomenium and Sinomenium.

Menispermum dauricum and S. cantalense are significantly different at $5 \%$ in the shape analysis (Table 4) and are significantly different at $1 \%$ for the number of transverse ridges (Table 5). Therefore, we consider them as two different species.

The difference between Palaeosinomenium and Wardensheppeya is significant at $5 \%$ but not at $1 \%$ (Table 4). Those two groups have comparatively few specimens, so the test is not as robust as it might be with more specimens. There is a difference between 


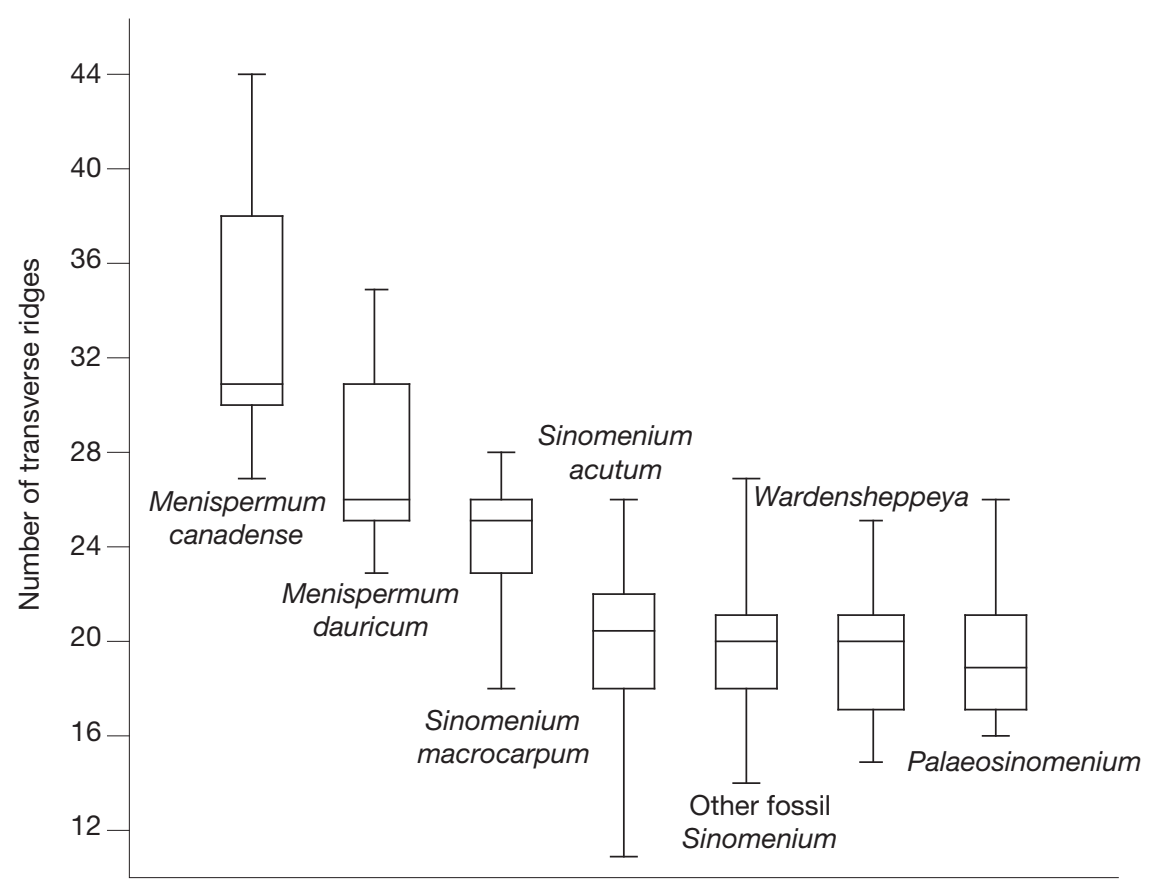

FIG. 5 - Comparisons of number of transverse ridges between groups. Mean, confidence intervals, and lower and upper limits are indicated for each group.

the two genera according to the first relative warp axis (Fig. 4). Therefore, we consider them different; morphometrics suggests some specimens (Fig. 4) might be transferred from one genus to the other.

Menispermicarpum rariforme seems to be linked with Palaeosinomenium through its obliquity (Fig. 4). Chandler (1961) stated that the ornamentation linked it with Cissampelos, even if they are very different in shape. As Cissampelos endocarps bear two lateral flanges on each side (Jacques 2009a) and $M$. rariforme only one, the statement of Chandler appears erroneous. She described the presence of the three rows of transverse ridges, but the inner one corresponds to the condyle side of the lateral flange. This feature is also sometimes seen on P. pulchrum. Therefore we believe that $M$. rariforme, a species based on only one specimen, should be included in Palaeosinomenium.

When describing Menispermum? taylori, Chandler (1964) stated that the inclusion of the species to the genus Menispermum is "tentative". The specimen is much abraded so the ornamentation is not observable. Chandler (1964) interpreted M.? taylori as having a straighter ventral margin than the other Menispermum species, being smaller in size than living species, and that the central area of $M$.? taylori is relatively larger than that of Wardensheppeya. Consequently, Chandler (1964) concluded that M.? taylori most closely resembles Menispermum. However, some fossil and recent Sinomenium have a relatively larger condyle than the known Wardensheppeya (Fig. 4). Furthermore, the features listed by Chandler (1964) appear to correspond more to Sinomenium than to Menispermum. Therefore, we suggest that M.? taylori should be included in Sinomenium.

Meyer \& Manchester (1997) described a fossil Menispermum from the Oligocene of the John Day Formation in North America, but no specific assignment was discussed. In our analysis (Fig. 4), this fossil is found to locate at the border in the plotting graph between $M$. dauricum and $M$. canadense. However, its high number of transverse ridges (37) makes it closer to M. canadense (Fig. 5). 
Menispermum reidii Geissert, Gregor \& Mai, 1990 is represented by a single specimen from the MioPliocene of eastern France (Geissert et al. 1990), while a putative second specimen was identified from the Pliocene of north western Italy as Menispermum cf. reidii (Cavallo \& Martinetto 2001). In our analysis (Fig. 4), they are both found close to $M$. dauricum, and the number of transverse ridges (31 and 33, respectively) is also similar to that of $M$. dauricum (Fig. 5). Therefore, we confirm the generic identification of this species and consider its nearest living relative as $M$. dauricum.

It has been proposed that Althaea crassicarpa resembles Menispermum (Reid 1920; Geissert et al. 1990). In our analysis (Figs 4; 6), this fossil "Menispermum crassicarpum" shows a close similarity to the extinct Sinomenium cantalense. This resemblance is also confirmed by both having the same number of transverse ridges (Fig. 5). However, the specimen is badly preserved, so the taxonomic status cannot be solved until more specimens become available.

\section{DIAGNOSTIC FEATURES}

The genus Palaeosinomenium differs from both Menispermum and Sinomenium by a more oblique and elongate endocarp (Chandler 1961). Our results (Figs 3F; 4) confirm the obliquity of the Palaeosinomenium endocarp. However, our study does not show any peculiar differences concern- ing the shape and relative size of foramen, even if this structure is highly variable (Fig. 2). Chandler (1961) described the ventral margin of Palaeosinomenium as concave to convex, the consensus shape of Palaeosinomenium (Fig. 3G) shows a flat ventral margin, confirming this interpretation. The difference in ornamentation between $P$. hantonense Chandler, 1963 and other species of the genus, namely that the former has more conspicuous ridges than the latter (Chandler 1963), is not diagnostic enough, as the ornamentation is quite variable in modern species of Menispermum and Sinomenium.

Sinomenium macrocarpum differs from other $\mathrm{Si}$ nomenium through its ornamentation; the number of ridges is higher than in $S$. acutum, confirming the results of Liu \& Jacques (2010).

Menispermum differs from other genera in the greater concavity of its ventral margin (Figs 3; 4) and in the higher number of transverse ridges. Menispermum endocarps are usually bigger than those of Sinomenium, so it seems that the number of transverse ridges is linked to the size of the endocarp. The function of the transverse ridges is not known, although their structural role in reinforcing the solidity of endocarp has previously been hypothesized with no further evidence (Jacques \& Bertolino 2008)

The differences mentioned above allow us to propose the following key and Table 6 for the determination of fossil species.

KeY TO THE FOSSIL ENDOCARPS OF THE SINOMENIUM-MENISPERMUM COMPLEX

1. Endocarp oblique Palaeosinomenium obliquatum

— Endocarp straight Menispermum reidii

2. Ventral margin concave

- Ventral margin more or less straight 3

3. Number of transverse ridges generally less than 22

- Number of transverse ridges generally more than 23 Sinomenium cantalense Sinomenium macrocarpum

In our study, modifications in the foramen are linked with shape modifications of the whole endocarp as shown by the first relative warp axis (Fig. 4). This can be linked to a structural constraint such that the foramen has to be on the endocarp. When the ventral margin concavity increases, the foramen hence cannot occupy a more "basal" position. Our measurement of the foramen (only two landmarks) can only describe its relative size and orientation; the shape 


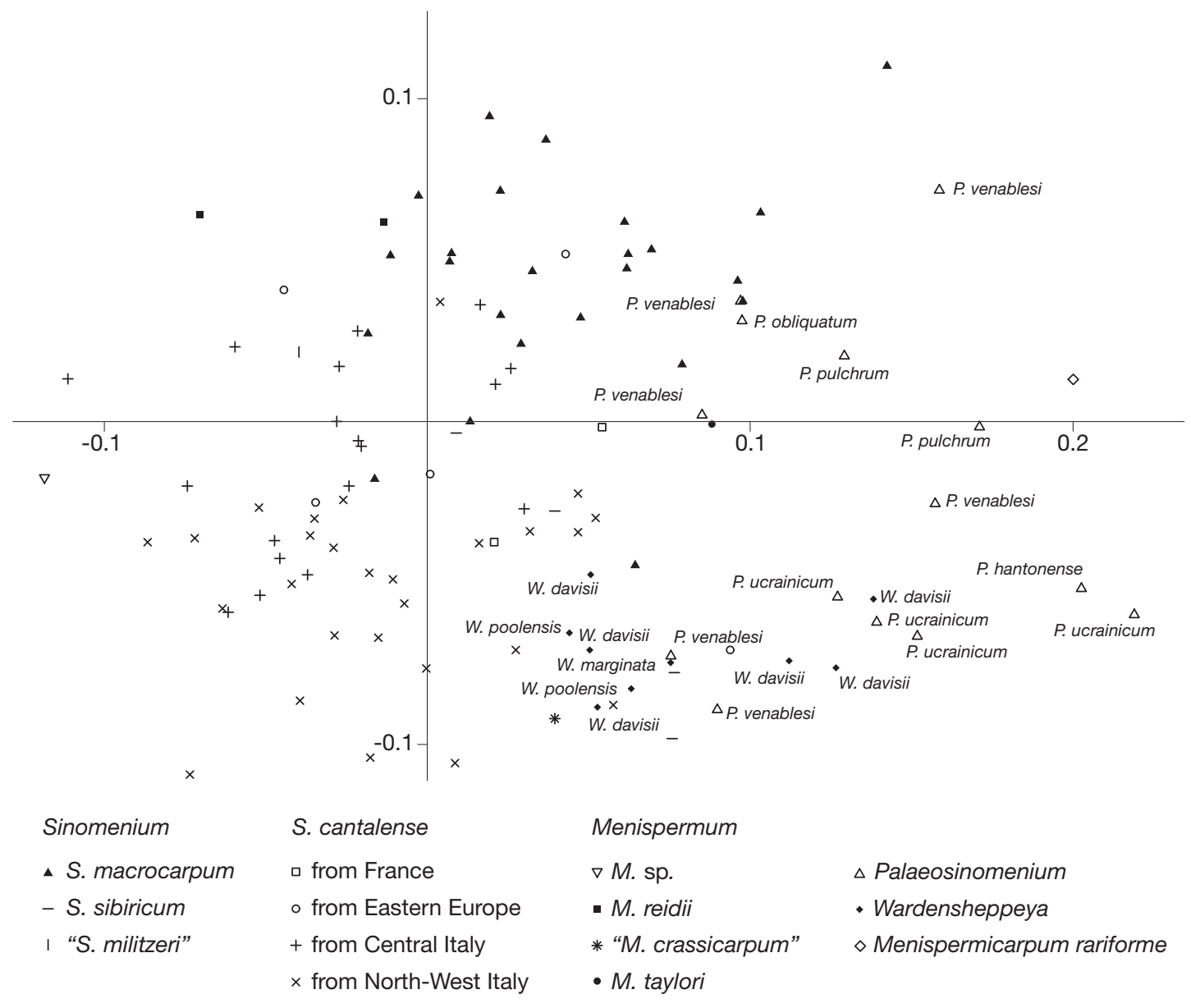

FIG. 6 - Detail of Figure 4 showing the placement of each fossil specimen of Menisermaceae endocarps in the relative warp analysis. "Sinomenium militzeri" is already recognized as a synonym of $S$. cantalense. The fossils of $S$. cantalense from different regions have been differentiated.

(circular vs. elongate) of the foramen cannot be described. The function of the foramen is still unknown. In the Menispermaceae, this feature is only present in the Menispermum-Sinomenium complex and Sarcopetalum (Jacques 2009a). The condyle is the result of the ossification of the placenta (Miers 1871; Dekker 1983). The foramen could be a means to continue to provide nutrition to the seed after ossification of the placenta; this personal hypothesis has to be verified with living material.

The modern species in the Menispermum-Sinomenium complex are also very variable in other morphological features. Sinomenium acutum has entire to lobed, glabrous to puberulous leaves; six sepals; six petals; nine or 12 stamens; nine staminodes; three carpels; and glabrous or pubescent fruits. In contrast, $M$. dauricum has glabrous to pubescent leaves: four to eight sepals; six to 12 petals; 12 or more stamens; six to 12 staminodes; two to four carpels; and glabrous fruit (Luo et al. 2008). The variations observed in the endocarps are not bigger than those observed in other organs. Therefore, we think that the fossil intraspecific variability should not be smaller than variability in modern specimens. 
TABLE 6. - Table summarizing endocarp characters of the Menispermum-Sinomenium complex.

\begin{tabular}{llll}
\hline & $\begin{array}{l}\text { Endocarp } \\
\text { obliquity }\end{array}$ & $\begin{array}{l}\text { Ventral } \\
\text { margin } \\
\text { concavity }\end{array}$ & $\begin{array}{l}\text { Number of } \\
\text { transverse } \\
\text { ridges }\end{array}$ \\
\hline $\begin{array}{c}\text { Palaeo- } \\
\text { sinomenium } \\
\text { obliquatum }\end{array}$ & Oblique & Straight & $\leq 22$ \\
$\begin{array}{c}\text { Menispermum } \\
\text { reidii }\end{array}$ & Straight & Concave & $\geq 30$ \\
$\begin{array}{c}\text { Sinomenium } \\
\text { cantalense }\end{array}$ & Straight & Straight & $\leq 22$ \\
$\begin{array}{c}\text { Sinomenium } \\
\text { macrocarpum }\end{array}$ & Straight & Straight & $\geq 23$ \\
\hline
\end{tabular}

\section{FOSSIL HISTORY}

In molecular analyses, Menispermum and Sinomenium form a monophyletic group (Wang et al. 2007; Hoot et al. 2009) that is one of the early-diverging clades amongst Menispermaceae (Ortiz et al. 2007; Wang et al. 2007; Hoot et al. 2009). For the characters of shape (Fig. 4) and ornamentation (Fig. 5), M. dauricum seems to be intermediate between Sinomenium acutum and $M$. canadense. It seems that the evolution is opposite of the first relative warp axis, i.e. towards a greater concavity of the ventral margin and a relatively thinner dorsal flange. The fossil $S$. macrocarpum represents another evolutionary trend to a greater size (Liu \& Jacques 2010), but without noticeable modification of shape.

The inclusion of Wardensheppeya in Sinomenium clearly expands the age of first appearance of this genus, i.e. early Palaeogene, when several other extant menispermaceous genera, e.g., Tinospora Miers were present as well (Chandler 1961; Jacques \& De Franceschi 2005).

Sinomenium, including Wardensheppeya, was common in the northern hemisphere in the Cenozoic (Manchester et al. 2009). The fossil genus Palaeosinomenium is found only in the Palaeogene of Europe (Chanlder 1961; Knobloch 1971; Tahktajan 1974; Jacques \& De Franceschi 2005) and North America (Manchester 1994). Fossil leaves assigned to Menispermum have been reported in the Palaeogene (references in Jacques [2009b]); however, some of the records are old and might not belong to Menispermum at all because the extant species for comparisons used by earlier workers in the fossil determinations have already been transferred to other menispermous genera (Jacques 2009b).

A Menispermum endocarp occurs in the Oligocene of North America (Meyer \& Manchester 1997) and resembles $M$. canadense, an endemic extant species in North America (Fig. 4). Interestingly, another endocarp species of Menispermum, $M$. reidii, is known from the Neogene of Europe (Geissert et al. 1990) and shows similarities with $M$. dauricum, an East Asian species (Fig. 4). The distribution of $M$. canadense and $M$. dauricum represents a classical eastern North America-East Asia disjunction, which has been suggested by molecular analysis to have formed as late as 0.28 million years (Xiang et al. 2000). The most recent molecular results indicate an older diversification of Menispermum: 8.2 million years (Jacques et al. 2011). Considering the geological history of these fossils, the present disjunct distribution of Menispermum may be relictual, which resulted from a contraction of a formerly wide distribution in the northern hemisphere to a restricted region. This pattern is shared with many other temperate seed plants (Manchester 1999; Manchester et al. 2009).

\section{TAXONOMIC CONCLUSIONS}

Based on the morphometric study, the following synonymy for Sinomenium and Palaeosinoemium is proposed.

\section{Genus Sinomenium Diels in Engl.}

$$
\text { Pflanzenreich 46, Menispermac: } 254 \text { (1910). }
$$

Wardenia Chandler non King, The Lower Tertiary Floras of Southern England I Paleocene floras. London Clay flora (supplement): 158; pl. 16, fig. 8 (1961).

Wardensheppeya Eyde, Taxon 19: 650 (1970).

\section{Sinomenium cantalense \\ (E.M. Reid) Dorofeev}

Trudy Botanicheskogo Instituta Akademii Nauk SSSR. Ser. 1. Flora i Sistematika Vyssikh Rastenii. Acta Instituti Botanici Academiae Scientiarum URPSS 11: 129 (1955). 
Menispermum cantalense E.M. Reid, Bulletin de la Société Géologique de France, sér. IV, 20: 66; pl. 3, figs 24, 25 (1920).

Sinomenium militzeri Kirchheimer, Botanisches Archiv 44: 384 (1943).

Sinomenium dielsii Szafer, Rozprawy Wydzial Matamatyczno-Przyroniczy PAU, Dzial B: Nauki Biologiczne, 72: 96; pl. 8, figs 15, 16, 21 (1947).

Menispermum taylori Chandler, The Lower Tertiary Floras of Southern England IV A summary and survey of findings in the light of recent botanical observations: 111; pl. 2, fig. 16 (1964).

Wardenia davisi Chandler, The Lower Tertiary Floras of Southern England I Palaeocene floras. London Clay flora (supplement): 158; pl. 16, fig. 8 (1961). — Wardensheppeya davisii (Chandler) Eyde, Taxon 19: 650 (1970).

Wardenia poolensis Chandler, The Lower Tertiary Floras of Southern England II Flora of the Pipe-clay Series of Dorset (Lower Bagshot): 62; pl. 7, figs 21, 22 (1962). Wardensheppya poolensis (Chandler) Eyde, Taxon 19: 650 (1970).

Wardenia marginata Chandler, The Lower Tertiary Floras of Southern England III Flora of the Bournemouth Beds; the Boscombe, and the Highcliff Sands: 84; pl. 12, figs 1722 (1963). - Wardensheppeya marginata (Chandler) Eyde, Taxon 19: 650 (1970).

Sinomenium sibiricum Dorofeev, in Takhtajan, Magnolophyta Fossilia URSS I: 96; pl. 117, figs 3-5, 7 (1974).

\section{Genus Palaeosinomenium Chandler}

The Lower Tertiary Floras of Southern England I Palaeocene floras. London Clay flora (supplement): 159 (1961).

\section{Palaeosinomenium obliquatum (Chandler) Chandler}

Bulletin of the British Museum (Natural History) Geology 5 (5): 118; pl. 25, figs 47-50 (1961).

Menispermum obliquatum Chandler, Upper Eocene Flora of Hurndle Hants I: 24; pl. 3, fig. 9 (1925).

Palaeosinomenium venablesi Chandler, The Lower Tertiary Floras of Southern England I Palaeocene floras. London Clay flora (supplement): 159; pl. 16, figs 9-13 (1961).
Palaeosinomenium pulchrum Chandler, The Lower Tertiary Floras of Southern England I Palaeocene floras. London Clay flora (supplement): 329; pl. 33, figs 5-7 (1961).

Menispermicarpum rariforme Chandler, The Lower Tertiary Floras of Southern England I Palaeocene floras. London Clay flora (supplement): 331; pl. 33, figs 11, 12 (1961).

Palaeosinomenium hantonense Chandler, The Lower Tertiary Floras of Southern England III Flora of the Bournemouth Beds; the Boscombe, and the Highcliff Sands: 82; pl. 12, figs 10-12 (1963).

Palaeosinomenium ucrainicum Dorofeev, in Takhtajan, Magnolophyta Fossilia URSS I: 96; pl. 117, figs 1114 (1974).

\section{Acknowkedgements}

The authors would like to thank the curators at the Institute of Botany, Chinese Academy of Sciences Herbarium (PE), Kunming Institute of Botany, Chinese Academy of Sciences Herbarium (KUN) and Missouri Botanical Garden Herbarium (MO) for providing modern samples; J. H. A van Konijnenburg and I. M. van Waveren of Naturalis, the National Natural History Museum, Leiden, The Netherlands for access to the Reid collection. YSL thanks East Tennessee State University and General Shale Brick Museum of Natural History for help in collecting fossils at the Gray Fossil Site in Tennessee. We thank Nina Chaopricha (University of Wisconsin) and Selena Y. Smith (University of Michigan) for checking the English. We thank anonymous reviewers for their helping comments on the manuscript. The research was in part financially supported by National Science Foundation grants EAR 0746105 to YSL, China postdoctor fellowship grant 20080431286, key laboratory, Kunming Institute of Botany, grant 086341121, CAS Young Scientists Fellowship (2009YB1-13), and NSFC Research Fellowship for International Young Scientists (40950110338) to FMBJ, National Natural Science Foundation of China (41030212) to ZKZ.

\section{REFERENCES}

Adams D. C., Rohlf F. J. \& Slice D. E. 2004. Geometric morphometrics: ten years of progress 
following the "revolution". The Italian Journal of Zoology 71: 5-16.

aiello G., Baratollo F., Barra D., Fiorito G., MazZarella A., Raia P. \& Viola R. 2007. — Fractal analysis of ostracod shell variability: a comparison with geometric and classic morphometrics. Acta Palaeontologica Polonica 52: 563-573.

APG II 2003. - An update of the Angiosperm Phylogeny Group classification for the orders and families of flowering plants: APG II. Botanical Journal of the Linnean Society 141: 399-436.

Basilici G., Martinetto E., Pavia G. \& Violanti D. 1997. - Paleoenvironmental evolution in the Pliocene marine-coastal succession of Val Chiusella (Ivrea, NW Italy). Bollettino della Società Paleontologica Italiana 36: 23-52.

BONNAN M. F. 2007. - Linear and geometric morphometric analysis of long bone scaling patterns in Jurassic Neosauropod Dinosaurs: their functional and paleobiological implications. The Anatomical Record 290: 1089-1111.

BONNAN M. F., FARLOW J. O. \& MASTERS S. L. 2008. Using linear and geometric morphometrics to detect intraspecific variability and sexual dimorphism in femoral shape in Alligator mississippiensis and its implications for sexing fossil archosaurs. Journal of Vertebrate Paleontology 28: 422-431.

BooksteIN F. L. 1986. - Size and shape spaces for landmark data in two dimensions. Statistical Science 1: 181-222.

BooKSTEIN F. L. 1991. - Morphometric Tools for Landmark Data: Geometry and Biology. Cambridge University Press, Cambridge, 435 p.

BOOKSTEIN F. L. 1997. — Landmark methods for forms without landmarks: localizing group differences in outline shape. Medical Image Analysis 1: 225-243.

BoOKSTEIN F. L. 2002. - Creases as morphometric characters, in MACLEOD N. \& Forey P. L. (eds), Morphology, Shape and Phylogeny. Taylor \& Francis, London: 139-174.

BOOKSTEIN F. L., CHERNOFF B., Elder R., HuMPHRIES J., SMith G. \& STRAuss R. 1985. - Morphometrics in Evolutionary Biology. The Academy of Natural Sciences of Philadelphia, Philadelphia, 277 p.

Cavallo P. \& MartinetTo E. 2001. — Flore carpologiche del Pliocene di Castelletto Cervo (Biella). Bollettino Museo Regionale di Scienze naturali 18: 277-343.

Chandler M. E. J. 1925. - The Upper Eocene flora of Hordle, Hants I. Palaeontographical Society, London, $32 \mathrm{p}$.

ChandLER M. E. J. 1961. - The Lower Tertiary floras of southern England I. Paleocene floras. London Clay flora (supplement). British Museum (Natural History), London, $354 \mathrm{p}$.

Chandler M. E. J. 1962. — The Lower Tertiary Floras of Southern England II. Flora of the Pipe-Clay series of Dorset (Lower Bagshot). British Museum (Natural History), London, $176 \mathrm{p}$.

CHANDLER M. E. J. 1963. - The Lower Tertiary Floras of Southern England III. Flora of the Bournemouth beds; the Boscombe, and the HighcliffSands. British Museum (Natural History), London, 169 p.

CHANDLER M. E. J. 1964. - The Lower Tertiary Floras of Southern England IV. A Summary and Survey of Findings in the Light of Recent Botanical Observations. British Museum (Natural History), London, $151 \mathrm{p}$.

CHEN I. \& MANCHESTER S. R. 2007. — Seed morphology of modern and fossil Ampelocissus (Vitaceae) and implications for phytogeography. American Journal of Botany 94: 1534-1553.

ClARKE K. R. 1993. - Non-parametric multivariate analysis of changes in community structure. Australian Journal of Ecology 18: 117-143.

DEKKER A. J. F. M. 1983. - A revision of the genera Penianthus Miers and Sphenocentrum Pierre (Menispermaceae) of West and Central Africa. Bulletin du Jardin botanique national de Belgique 53: 17-66.

Delabroye A. \& Cronier C. 2008. - Ontogeny of an Ordovician trinucleid (Trilobita) from Armorica, France: a morphometric approach. Journal of Paleontology 82: 800-810.

Diels L. 1910. - Menispermaceae, in ENGLER A. (ed.), Das Pflanzenreich IV, 94. Wilhelm Engelmann, Leipzig: 1-345.

Doria G., Jaramillo C. A. \& Herrera F. 2008. Menispermaceae from the Cerrejón formation, Middle to Late Paleocene, Colombia. American Journal of Botany 95: 954-973.

Geissert F., Gregor H.-J. \& MAi D. H. 1990. — Die "Saugbaggerflora" eine Frucht- und Samenflora aus dem Grenzbereich Miozän - Pliozän von Sessenheim im Elsass (Frankreich). Documenta Naturae 57: 1-208.

Hammer Ø., Harper D. A. T. \& Ryan P. D. 2001. PAST: Paleontogical Satistical software for education and data analysis. Palaeontologia Electronica 4.

HaRVATI K. 2003. - The Neanderthal taxonomic position: models of intra- and inter-specific craniofacial variation. Journal of Human Evolution 44: 107-132.

Holliday T. W., Hutchinson V. T., Morrow M. M. B. \& LivesAY G. A. 2010. — Geometric morphometric analyses of hominid proximal femora: taxonomic and phylogenetic considerations. HOMO - Journal of Comparative Human Biology 61: 3-15.

Hoot S. B., Zautke H., Harris D. J., Cran P. R. \& NeVES S. S. 2009. - Phylogenetic patterns in Menispermaceae based on multiple chloroplast data. Systematic Botany 34: 44-56.

JACQUES F. M. B. 2009a. - Survey of the Menispermaceae endocarps. Adansonia 31 (1): 47-87.

JaCQUeS F. M. B. 2009b. - Fossil History of the Menispermaceae (Ranunculales). Annales de Paléontologie 95: 53-69. 
JaCQues F. M. B. \& De Franceschi D. 2005. — Endocarps of Menispermaceae from Le Quesnoy outcrop (Sparnacian facies, Lower Eocene, Paris Basin). Review of Palaeobotany and Palynology 135: 61-70.

Jacques F. M. B. \& BerTOlino P. 2008. - Molecular and morphological phylogeny of Menispermaceae (Ranunculales). Plant Systematics and Evolution 274: 83-97.

JACQUES F. M. B. \& ZHOU Z. K. 2010. - Geometric morphometrics: a powerful tool for the study of shape evolution in Menispermaceae endocarps. Taxon 59: 881-895.

Jacques F. M. B., Wang W., Ortiz R. D. C., Li H. L., ZHOU Z. K. \& CHEN Z. D. 2011. - Integrating fossils in a molecular-based phylogeny and testing them as calibration points for divergence time estimates in Menispermaceae. Journal of Systematics and Evolution 49: 25-49.

JENSEN R. J. 1990. — Detecting shape variation in Oak leaf morphology: a comparison of rotational-fit methods. American Journal of Botany 77: 1279-1293.

JENSEN R. J. 2003. - The conundrum of morphometrics. Taxon 52: 663-671.

Kessler P. J. A. 1993. - Menispermaceae, in KUBITZKI K., ROHWER J. G. \& BITTRICH V. (eds), The Families and Genera of Vascular Plants, 2. Springer, Berlin: 402-418.

Knobloch E. 1971. - Fossile Früchte und Samen aus der Flyschzone der mährischen Karpaten. Sbornik Geologických véd. Paleontologie 13: 7-46.

LiU Y. S. \& JACQUES F. M. B. 2010. - Sinomenium macrocarpum sp. nov. (Menispermaceae) from the uppermost Miocene to lowermost Pliocene of Gray, northeast Tennessee, USA. Review of Palaebotany and Palynology 159: 112-122.

LOHMANN G. P. 1983. - Eigenshape analysis of microfossils: a general morphometric procedure for describing changes in shape. Mathematical Geology 15: 659-672.

Luo X. R., Chen T. \& Gilbert M. G. 2008. - Menispermaceae, in Wu Z., RAVEN P. H. \& Hong D. (eds), Flora of China Volume 7: Menispermaceae through Capparaceae. Missouri Botanical Garden Press, St. Louis: 1-31.

MaI D. H. 1997. - Die oberoligozänen Floren am Nordrand der Sächsischen Lausitz. Palaeontographica, Abteilung B 244: 1-124.

MANCHESTER S. R. 1994. - Fruits and seeds of Middle Eocene nut beds flora, Clarno formation Oregon. Palaeontographica Americana 58: 1-205.

MANCHESTER S. R. 1999. - Biogeographical relationships of North American Tertiary floras. Annals of the Missouri Botanical Garden 86: 472-522.

Manchester S. R., Chen Z. D., Lu A. M. \& Uemura K. 2009. - Eastern Asian endemic seed plant genera and their paleogeographic history throughout the northern hemisphere. Journal of Systematics and Evolution 47: 1-42.

MARTINETTO E. 1995. - Significato cronologico e paleoambientale dei macrofossili vegetali nell'inquadramento stratigrafico del "Villafranchiano" in alcuni settori del Piemonte. PhD diss. Dipartimento di Scienze della Terra di Torino, Torino, $149 \mathrm{p}$.

MarTinetTo E. 2001. - The role of central Italy as a centre of refuge for thermophilous plants in the late Cenozoic. Acta Palaeobotanica 41: 299-319.

Meyer H. W. \& Manchester S. R. 1997. - The Oligocene Bridge Creek flora of the John Day Formation, Oregon. University of California Publications in Geological Sciences 141: 1-195.

Miers J. 1871. - Contributions to Botany 3. A Complete Monograph of the Menispermaceae. Williams \& Norgate, London and Edinburgh, $402 \mathrm{p}$.

McLellan T. \& Endler J. A. 1998. - The relative success of some methods for measuring and describing the shape of complex objects. Systematic Biology 47: 264-281.

Monteiro L. R., Di Beneditto A. P. M., Guillermo L. H. \& Rivera L. A. 2005. - Allometric changes and shape differentiation of sagitta otoliths in sciaenid fishes. Fisheries Research 74: 288-299.

Nyberg K. G., Ciampaglio C. N. \& Wray G. A. 2006. - Tracing the ancestry of the Great White Shark, Charcharodon carcharias, using morphometric analysis of fossil teeth. Journal of Vertebrate Paleontology 26: 806-814.

Olsson A., Nybom, H. \& Prentice H. C. 2000. Relationships between Nordic dogroses (Rosa L. sect. Caninae, Rosaceae) assessed by RAPDs and elliptic Fourier analysis of leaflet shape. Systematic Botany 25: 511-521.

Ortiz R. D. C., Kellogg E. A. \& Van der WerfF H. 2007. - Molecular phylogeny of the Moonseed family (Menispermaceae): implications for morphological diversification. American Journal of Botany 94: $1425-1438$.

ReID E. M. 1920. - A comparative review of Pliocene floras, based on the study of fossil seeds. Quarterly Journal of the Geological Society 76: 145-161.

RoHLF F. J. 1986. — Relationships among eigenshape analysis, Fourier analysis, and analysis of coordinates. Mathematical Geology 18: 845-854.

RohlF F. J. 1993. - Relative warps analysis and an example of its application to mosquito wings, in MARCUS L. F., Bello E. \& Garcia-Valdecasas A. (eds), Contributions to Morphometrics, Vol. 8. Monografias del Museo Nacional de Ciencias Naturales (CSIC), Madrid: 131-159.

Rohlf F. J. 2006a. - tpsDig, Digitize Landmarks and Outlines, version 2.10. Department of Ecology and Evolution, State University of New York at Stony Brook. RoHLF F. J. 2006b. — tpsDig, File Utility Program, ver- 
sion 1.38. Department of Ecology and Evolution, State University of New York at Stony Brook.

RohlF F. J. 2007. - tpsRelw, Relative Warps Analysis, version 1.45. Department of Ecology and Evolution, State University of New York at Stony Brook.

Rohlf F. J., LOY A. \& CORTI M. 1996. - Morphometric analysis of Old World Talpidae (Mammalia, Insectivora) using partial-warp scores. Systematic Biology 45: 344-362.

Rohlf F. J. \& Slice D. 1990. Extensions of the Procrustes method for the optimal superimposition of landmarks. Systematic Zoology 39: 40-59.

Savolainen V., Chase M. W., Hoot S. B., Morton C. M., Soltis D. E., BAYER C., FAY M. F., De BruijN A. Y., Sullivan S. \& QIU Y. L. 2000. - Phylogenetics of flowering plants based on combined analysis of plastid atp $\mathrm{B}$ and $r b c \mathrm{~L}$ gene sequences. Systematic Biology 49: 306-362.

ShipunOV A. B. \& BATEMAN R. M. 2005. - Geometric morphometrics as a tool for understanding Dactylorhiza (Orchidaceae) diversity in European Russia. Botanical Journal of the Linnean Society 85: 1-12.

Slice D. E., Bookstein F. L., Marcus L. F. \& Rohlf F. J. 1996. - A glossary for geometric morphometrics, in MARCus L. F., CorTi M., LOY A., NAYLOR G. J. P. \& Slice D. E. (eds), Advances in Morphometrics. Plenum Press, New York: 531-551.

SNeATH P. H. A. \& SOKal R. R. 1973. - Numerical Taxonomy: the Principles and Practice of Numerical
Classification. W. H. Freeman \& Company, San Francisco, $573 \mathrm{p}$.

SOKAL R. R. \& SNEATH P. H. A. 1963. - Principles of Numerical Taxonomy. W. H. Freeman \& Company, San Francisco, 359 p.

SZAFER W. 1961. — Miocene Flora from Stare Gliwice in Upper Silesia. Prace Instytut Geologiczny 33: 1-205.

TAKHTAJAN A. 1974. - Magnoliophyta fossilia URSS I. Magnoliaceae-Eucommiaceae. Nauka, Leninopoli, $188 \mathrm{p}$.

Wang W., Wang H. C. \& Chen Z. D. 2007. — Phylogeny and morphological evolution of tribe Menispermeae (Menispermaceae) inferred from chloroplast and nuclear sequences. Perspectives in Plant Ecology, Evolution and Systematics 8: 141-154.

Webster M. \& Hughes N. C. 1999. - Compaction related deformation in Cambrian olenelloid trilobites and its implication for fossil morphometry. Journal of Paleontology 73: 355-371.

Whitenack L. B. \& GotTFried M. D. 2010. - A morphometric approach for addressing tooth-based fossil delimitation in fossil mako sharks, Isurus (Elasmobranchii: Lamniformes). Journal of Vertebrate Paleontology 30: 17-25.

Xiang Q. Y., Soltis D. E., Soltis P. S., Manchester S. R. \& CRAWFORD D. J. 2000. - Timing the eastern Asian-eastern North American floristic disjunction: molecular clock corroborates paleontological estimates. Molecular Phylogenetics and Evolution 15: 462-472.

Submitted on 11 March 2010; accepted on 5 January 2011. 


\section{APPENDIX 1}

List of studied specimens. Abbreviations: ETMNH, East Tennessee Museum of Natural History; NHM, Natural History Museum of London; Tor, Dipartimento di Scienze della Terra, University of Torino.

\section{MODERN SPECIMENS}

Menispermum canadense Linnaeus: KUN 0165280; J. Miller et al. 5500 (MO); S. D. Swanson 2328 (MO);

Menispermum dauricum DC.: KUN 0165236; KUN 0165256; PE 01071064; PE 01604656; PE 01071135; PE 0107010; PE 010711343;

Sinomenium acutum (Thunb.) Rehder \& Wilson: KUN 0165595; KUN 0165572; KUN 0165585; KUN 0166855; KUN 0165604; KUN 0165594; KUN 0165565; KUN 0165610; KUN 0166336; KUN 0165600; KUN 0575891; KUN 0166848; KUN 0165631; KUN 0165642; KUN 0165650; KUN 0165624; Takhtajan 1974 (2 specimens).

FOSSIL SPECIMENS

Menispermicarpum rariforme Chandler, 1961: V.34573 (NHM);

Menispermum reidii Geissert, Gregor \& Mai, 1990: P1336-440;

Menispermum cf. reidii Geissert, Gregor \& Mai, 1990: GA5 A4L (Tor);

Menispermum taylori Chandler, 1964: V.45223 (NHM);

Palaeosinomenium hantonense Chandler, 1963: V.43306 (NHM);

Palaeosinomenium obliquatum (Chandler) Chandler, 1961: V.20049 (NHM);

Palaeosinomenium pulchrum Chandler, 1961: V.34585 (NHM); V.34586 (NHM);

Palaeosinomenium ucrainicum Dorofeev, 1974: K430 (1, 2, 3); K431;

Palaeosinomenium venablesi Chandler, 1961: V.29839 (NHM); V.29840 (NHM); V.30578a (NHM); V.30579 (NHM); UF 4595; USNM 354561;

Sinomenium cantalense (E.M.Reid) Dorofeev, 1955: K432-2 (Ukraine); K531 (Abkhazia); V.25625 (NHM); V.25684 (NHM) (France); BG2 A4V (Tor), BO1 A2V (2 specimens, Tor), CO1 A6T (Tor), CV5 A0E (Tor), CV106 A2G (7 specimens, Tor), CV106 A6H (6 specimens, Tor), GA1 A2T (4 specimens, Tor), GA3 B1Q (Tor), RB1 A2R (Tor), RB1 A6G (Tor), RDB1 A1M (Tor) (NW Italy); NJ0 B5B (4 specimens, Tor), NJ1 B7F (Tor), NJ4 B5D (Tor), NJ5 B5C (13 specimens, Tor), PU105395 (central Italy); 4 specimens published in Szafer (1961) without collection number (Poland);

Sinomenium macrocarpum Liu \& Jacques, 2010: ETMNH 3812- 3827; 3832-3839;

Sinomenium sibiricum Dorofeev, 1974: K518 (3, 4, 5 ,6);

Wardensheppeya davisii (Chandler) Eyde, 1970: V. 29838 (NHM); V.51640 (NHM); without number (NHM); 40036 (P); 40037 (P);

Wardensheppeya marginata (Chandler) Eyde, 1970: V.43309 (NHM);

Wardensheppeya poolensis (Chandler) Eyde, 1970: V.40457 (NHM); V.40487 (NHM). 